\title{
Francisco Delich: de la noticia más antigua hacia una historia intelectual
}

César Tcach ${ }^{1}$

La noticia más antigua que registra la prensa acerca de la actuación pública de Francisco Delich data de octubre de 1959, con motivo de la realización en Córdoba del VI Congreso Eucarístico Nacional. El evento - promovido activamente por el Vaticano- contó con la presencia del legado pontificio Cardenal Fernando Cento. Vivado por una multitud de creyentes en su recorrido por el centro de la ciudad, el Cardenal Legado del Pontífice proclamó a Córdoba «Capital religiosa de la República». Asimismo, hizo pública una nota, escrita de su puño y letra, en la que elogiaba a la prensa del Arzobispado cordobés: «Saludo efusivamente al diario LOS PRINCIPIOS, valeroso adalid del ideal católico y formulo el voto de que siga con creciente empuje combatiendo las santas batallas, sostenido moral y materialmente por cuantos son sinceros creyentes.»²

Aún no apagados los ecos del conflicto entre educación pública y educación «libre» (expresión empleada por los partidarios de la enseñanza privada universitaria) quedaba claro a que «santas batallas» se refería el legado pontificio. El gobierno provincial declaró asueto. En estas circunstancias, se planteó en la UNC la disyuntiva de adherir o no al cese de actividades. El rector Jorge Orgaz había viajado a Buenos Aires sin dejar resolución alguna relativa a un asueto en la universidad, pero el secretario general José María Escalera con la aquiescencia del vicerrector Benjamín Cornejo lo promovieron. En este contexto, Francisco Delich fue consecuente con sus ideales reformistas y valores laicos: la universidad no debía adherirse al asueto; y obró en consecuencia. Los estudiantes reformistas abrieron las puertas de la sede de la UNC situada en la calle Obispo Trejo

\footnotetext{
${ }^{1}$ Investigador Principal del Consejo Nacional de Investigaciones Científicas y Técnicas (CONICET).

${ }^{2}$ Texto del autógrafo regalado por Cardenal Cento al directorio del periódico. Véase Los Principios, 10/10/1959. Las cursivas son mías.
} 
y de las facultades de ingeniería, medicina y derecho, donde el tema se debatió en las aulas, hasta entrada la noche. ${ }^{3}$

La agrupación católica Ateneo Universitario expresaba indignada:

«Un minúsculo grupo de estudiantes reformistas -con la complicidad de los consiliarios estudiantiles Delich y Viera Alonso- tomó el edificio de la universidad a las 18,55 hrs de hoy colocando pizarrones en los que se anunciaba que la universidad no se había adherido al VI Congreso Eucarístico y funcionaba normalmente. Queda así, una vez más al descubierto, la falsa neutralidad del laicismo reformista, que no ha vacilado en «tomar» por asalto la Casa de Trejo (...) poniendo en evidencia su claro ateísmo marxista». ${ }^{4}$

Francisco Delich y sus compañeros -los conciliarios Valiana y Viera Alonso- se defendieron, expresando en un comunicado que «la universidad de Córdoba no adhirió al asueto decretado por el gobierno de la provincia» y que no había «decreto alguno firmado por el rector interino disponiendo el cese de las actividades en la universidad». La aclaración no impidió el anatema del diario Los Principios, cuya condena a Delich se remontó a los orígenes de la Reforma Universitaria de 1918. En un texto titulado «Hoy como ayer y como siempre. ¿Hasta cuándo?» responsabilizaba a:

«un núcleo estudiantil que conocemos perfectamente en los móviles que inspiran su acción y las vinculaciones que tiene con extremismos foráneos. Por ello, no nos extraña su repulsa a lo que sea religioso, que hace a la esencia de la argentinidad, que está empeñado en destruir para que haga presa de ella el comunismo (...) Tampoco nos extrañan los procedimientos que arbitran para sus fines: son los mismos que usaron hace más de cuarenta años». ${ }^{5}$

Como contrapartida, la Federación Universitaria de Córdoba (FUC) respaldó -en nombre de la autonomía universitaria- la posición liderada por Delich, quien había calificado sin nombrarlos al vicerrector y al secretario general de la UNC como «funcionarios sectarios y al servicio de los intereses del Arzobispado». ${ }^{6}$

\footnotetext{
${ }^{3}$ La Voz del Interior, 08/10/1959.

${ }^{4}$ Los Principios, 08/10/1959.

${ }^{5}$ Los Principios, 08/10/1959.

${ }^{6} \mathrm{La}$ Voz del Interior, 08/10/1959.
} 
A partir de esta matriz política-cultural, dominada por los clivajes propios de lo que alguna vez José Aricó denominó «ciudad de frontera», es menester aclarar que Delich era la expresión de un universo intelectual que combinaba liberalismo radicalizado, laicismo y reformismo social. ${ }^{7}$ No militaba en la UCR, sus simpatías se situaban por entonces más cerca del Partido Demócrata Progresista, cuya proa visionaria había sido Lisandro de la Torre.

Desde el punto de vista de su itinerario intelectual, es posible distinguir -al menos- tres etapas. Estudiante y vecino de barrio Clínicas -donde su pasión por Belgrano se combinaba con la defensa de la universidad pública y laica que pregonaban los herederos de la Reforma Universitariase recibió de abogado en 1960. Luego viajó a París para realizar estudios de posgrado en economía y sociología en La Sorbona. Vivió tres años en Francia, disfrutó y discutió sobre el devenir humano en las noches de la bohemia parisina y conoció a su maestro: Alan Touraine. Se sentía cómodo dialogando críticamente con las obras de Durkheim, Max Weber, y Raymond Aron. En esta época se familiarizó también con la obra de Antonio Gramsci en virtud de su amistad con José Aricó, intelectual marxista que proponía una mirada crítica del dogmatismo stalinista.

Entre 1964-65 publicó tres textos en Pasado y Presente, la célebre revista que se proponía renovar desde Córdoba la cultura política de la izquierda argentina. En este primer Delich, el influjo de los intelectuales franceses se combinaba con la mirada innovadora de los disidentes de la izquierda tradicional, entre los que se contaban el propio Aricó, el filósofo Oscar del Barco, el semiólogo y pensador Héctor Schmucler, el economista Aníbal Arcondo y el sociólogo Juan Carlos Portantiero.

En 1993 Delich recordaba en un artículo publicado por la revista Estudios Sociales, que cuando volvió de Francia, su amigos le preguntaban acerca de la percepción que tenían los europeos sobre Argentina:

«Cómo nos ven? Cuando estaba lucido -no era frecuente- respondía: no nos ven. Cuando voluntarista -un poco más seguido- agregaba, pero ya nos verán. Había vivido tres años en París, y al regreso, aquella obsesiva pregunta era inevitable. No era del todo cierto (...) miraban pero no comprendían». ${ }^{8}$

\footnotetext{
${ }^{7}$ José Aricó, (1989), «Tradición y modernidad en la cultura cordobesa», Plural $\mathrm{N}^{\circ} 13$, Córdoba.

${ }^{8}$ DELICH, Francisco, (1993), «Los mitos argentinos», en revista Estudios Sociales $\mathrm{N}^{\circ} 4$, Santa Fe: UNL. p. 203.
} 
Fruto de esta primera época fue su libro Crisis y Protesta Social, centrado en el análisis del «cordobazo» y publicado por primera vez en 1970. Lo había terminado de escribir entre enero y febrero de ese año en Toulouse. Los primeros capítulos ya habían comenzado a difundirse a través de la revista Jerónimo, que se editaba en Córdoba y desafiaba a la dictadura de Onganía. En ese mismo año publicó otro libro, dedicado al problema agrario y la cuestión social en el norte argentino: Tierra y conciencia campesina en Tucumán. Pocos años después aparecía en esas mismas tierras el más notable ensayo de guerrilla rural de la historia argentina. Afianzaba, así, una mirada sociológica fundada en los mejores filones teóricos de su época sobre dos provincias, Córdoba y Tucumán, para tratar de entender la política argentina previa al golpe del 76.

Durante la dictadura, en su condición de secretario ejecutivo de CLACSO (Consejo Latinoamericano de Ciencias Sociales), emergió lo que podríamos llamar un segundo Delich. A la sombra del terrorismo de Estado fundó, junto a Fernando Henrique Cardozo (futuro presidente de Brasil), Norbert Lechner y Enzo Faletto la revista Crítica y Utopía (1978). Desde sus páginas sentó posición en la crucial batalla de ideas que desgarraba al progresismo: el reemplazo del paradigma de la revolución por el de una democracia avanzada en términos sociales, políticos y culturales.

$\mathrm{Al}$ calor de los procesos de transición democrática de la década del ochenta, emergió un tercer Delich. Es el que se descubre a través de sus tres tomos de La invención de la universidad publicados entre 1987 y1992; en su obsesión por construir una universidad popular y al mismo tiempo, de excelencia, romper el corsé de las disciplinas tradicionales mediante estudios interdisciplinarios y potenciar los posgrados en ciencias sociales. Es el que se manifiesta en su perfil de constructor de instituciones: rector de la UBA (1983-85) y de la UNC (1989-95), fundador del Centro de Estudios Avanzados (con el aporte de exiliados provenientes de México, Ecuador, Brasil, Israel y España) y de la Biblioteca Aricó (uno de los más importantes repositorios de la cultura de izquierdas en América Latina) alguna vez se preguntó: ¿ ¿He cambiado? Y se respondió a sí mismo: «con toda seguridad pero no tanto para no reconocer las propias huellas. He cambiado la mirada pero no el horizonte». 